International Journal of Pharmaceutics \& Pharmacology

Available Online: https://ijpp.edwiserinternational.com

\title{
A Review on Post COVID-19 Effects
}

\author{
Bhakti Kundlik Lonkar* and Ketakee Prakash Gosavi \\ Department of Pharmacology, Dattakala College of Pharmacy, Savitribai Phule Pune University, Taldaund, Pune, Maharashtra, \\ India
}

Article info

Received 01 January 2021

Revised 03 February 2021

Available Online 13 February 2021

*Corresponding author: Bhakti Kundlik Lonkar, Department of Pharmacology, Dattakala College of Pharmacy, Savitribai Phule Pune University, Taldaund, Pune, Maharashtra, India

\begin{abstract}
The whole world is under threat, due to the pandemic situation of COVID19. According to the data, more than 30 million people were infected and over 1 million died all over the world. The clinical data states that, people recovered from COVID develop long-term effects on their body. More than 4 million people in US, UK and Sweden had symptoms after recovery from COVID, which was termed as post-acute COVID-19. The serious effects were observed like pulmonary dysfunction, myocardial inflammation and impaired mental health. There were serious heart and kidney related issues, which were observed. However, the people are in great danger, those who are suffering from post COVID effects.
\end{abstract}

Keywords: Post-acute COVID-19; Pulmonary dysfunction; Myocardial inflammation; Impaired mental health; Post COVID effects

\section{Introduction}

COVID-19 is caused by severe acute respiratory syndrome. Though the recovery from COVID is increasing, recovered cases are diagnose with long term consequences. It was observed that the patient suffering serious COVID infections, develop post-acute syndrome. According to the clinical report, the people with post-acute syndrome, develop general symptoms and specific organ dysfunction [1-5].

\section{What is post-acute COVID-19?}

Post-acute syndrome was well observed in patients, those who are recovering from serious COVID infection [1]. It was stated that, post-acute COVID extend more than 3 weeks from the onset of first symptoms and the chronic COVID will extend more than 12 weeks [6]. According to the survey, only $65 \%$ of US population had returned to their healthy state in 14-21 days after a positive test [6,7].

Even mild COVID-19 may result from long term symptoms. These symptoms include cough, fever, shortness of breath, chest pain, headaches, muscle pain, gastrointestinal upset, rashes and depression and other mental disorders $[6,8,9]$ (Figure 1).

In short, though the patients had recovered from COVID, they had bad impact on their body.

The post COVID-19 has serious impact on various organs of the body. The table below shows, post COVID-19 effects on various organ systems (Table 1).

\section{Respiratory system complications}

As we know, COVID-19 is serious infection caused by SARS-CoV-2, which mainly infects respiratory system. Breathlessness is common after acute COVID-19. The patients recovered from acute COVID -19, are at high risk to develop long term impairment of lung. As everyone knows, this virus affects various body systems, the lungs are affected most. The effects on respiratory system includes mucous membrane damage, haemorrhage, pulmonary consolidation and alveolar fibrosis [10].

There are various test for measuring lung function, which includes spirometry, $\mathrm{x}$-ray and CT scans. 


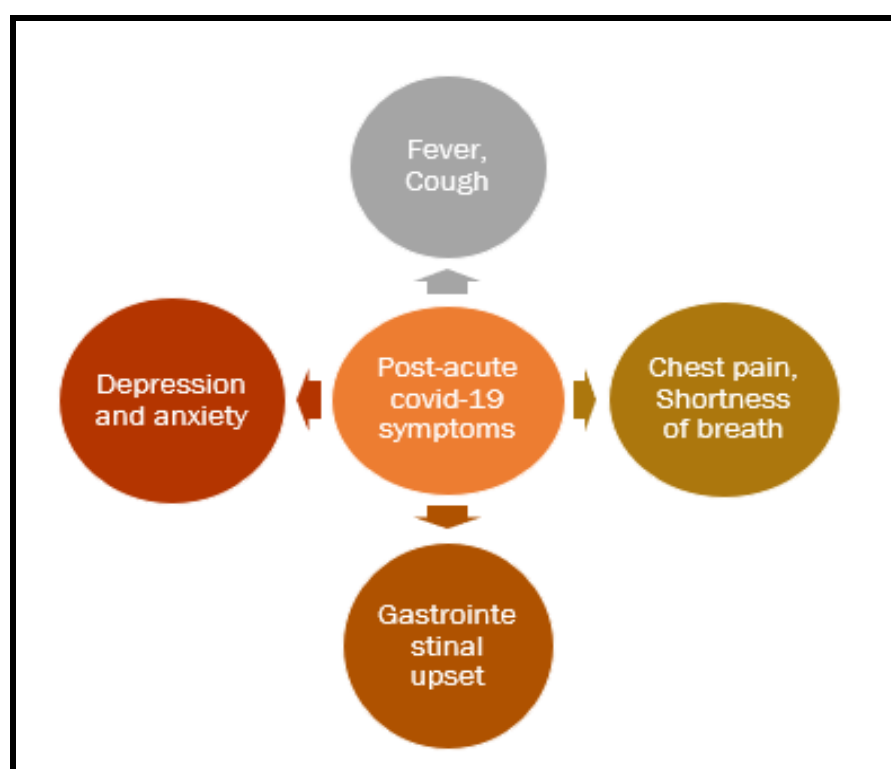

Figure 1: Post-acute COVID-19 symptoms

British Thoracic Society states that, chronic cough last for more than 8 weeks. [611]. Till that time before serious cough infection, it should be managed by simple breathing exercises.

Due to high levels of LDH during acute illness increases the risk of pulmonary fibrosis [12]. The clinical data states that, patients who develop fibrosis after recovery, generally have serious infections during hospitalization [12]. High levels of CRP and IL-6 at the time of illness, may lead to formation of fibrosis during recovery $[12,13]$.

Though the patients are recovering from COVID, people are under great danger in developing serious issues related to respiratory system.

Table 1: Post COVID-19 impact on various organs.

\begin{tabular}{|c|l|l|}
\hline $\begin{array}{l}\text { S. } \\
\text { No. }\end{array}$ & Organ system & Post COVID-19 effects \\
\hline 1 & $\begin{array}{l}\text { Respiratory } \\
\text { system }\end{array}$ & $\begin{array}{l}\text { Long term impairment of lungs, } \\
\text { alveolar fibrosis. }\end{array}$ \\
\hline 2 & $\begin{array}{l}\text { Cardiovascular } \\
\text { system }\end{array}$ & $\begin{array}{l}\text { Myocardial infraction, } \\
\text { pericarditis, heart failure }\end{array}$ \\
\hline 3 & $\begin{array}{l}\text { Nervous } \\
\text { system }\end{array}$ & $\begin{array}{l}\text { Anxiety, depression, trauma, } \\
\text { seizures, encephalitis }\end{array}$ \\
\hline 4 & $\begin{array}{l}\text { Excretory } \\
\text { system }\end{array}$ & Kidney damage, proteinuria \\
\hline
\end{tabular}

\section{Cardiovascular system complications}

Cardiopulmonary complications include serious conditions like myocardial infraction, pericarditis and dysrhythmias [6]. These problems are common in patients with pre-existing cardiovascular diseases.

Chest pain is very common in patient recovered from COVID. Left ventricular systolic dysfunction and heart failure are observed. The clinical data suggest that, COVID-19 has been demonstrated to interact with ACE-2. After the interaction it enters the host cells $[14,15]$. Due to the binding of SARS-CoV-2 with ACE2 , causes lung injury $[14,16]$. Due to the entry of virus there is increase in levels of angiotensin-2. And the increased ACE-2 receptor, increases the load of virus.

The cardiac complication in COVID is very dangerous issue, to those patients who had history of cardiovascular diseases and have long term effects after recovery.

\section{Effect on mental health}

There are many articles on COVID-19 and mental health, which states, individual reactions to the pandemic situation like anxiety and depression.

Data suggest that post-acute COVID-19 is mostly related to low mood, hopelessness and difficulty in sleeping [6]. The post-traumatic stress, which occurs mainly in healthcare workers [17]. The evidence indicates that, women, younger population and those who have poor quality of sleep are at high risk in developing mental health related issues [18]. The problems related to mental health are associated with poverty, discrimination and social exclusion [19]. Many survey have reported that after recovery from COVID, there is increased levels of anxiety and depression.

\section{Impact on older patients}

The infection of COVID-19 affects more severely in elderly patients [20]. Those who survive are under great danger in developing depression and delirium [11]. The post- COVID pain is very common in older patients $[6,21]$. The older population has poor immune system. So, the older patients after recovery from COVID have high risk of developing problems related to mental health, cardiovascular system and respiratory system.

\section{Impact on brain}

It was observed that, ischaemic stroke, seizures, encephalitis and cranial neuropathies develop after the recovery from COVID-19 [6,22]. The common symptoms like headaches, dizziness and cognitive blunting are observed [6,9]. COVID-19 impact on nervous is long term.

The virus enter the brain through blood brain barrier. After entry of the virus into brain, meninges and choroid 
plexus become infected. The hypothalamus is the target point of the virus and due to this there is contribution of poor immune system. Various cytokines regulated in COVID-19. These are powerful in activating hypothalamic-pituitary-adrenocortical (HPA) axis $[23,24]$. The HPA is activated by dysfunction of blood brain barrier [23,24]. Due to activation of HPA, there is release of norepinephrine and glucocorticoids. These mediators decrease the immune system by $\mathrm{T}$ cell apoptosis and natural killer cell deficiency. Because of these the defense mechanism of the body collapse (Figure 2).

As we know strong immunity is very to recover from any infection. But in case of COVID-19 complication of brain, the immune system is destroyed badly and has its long term effect after recovery from COVID.

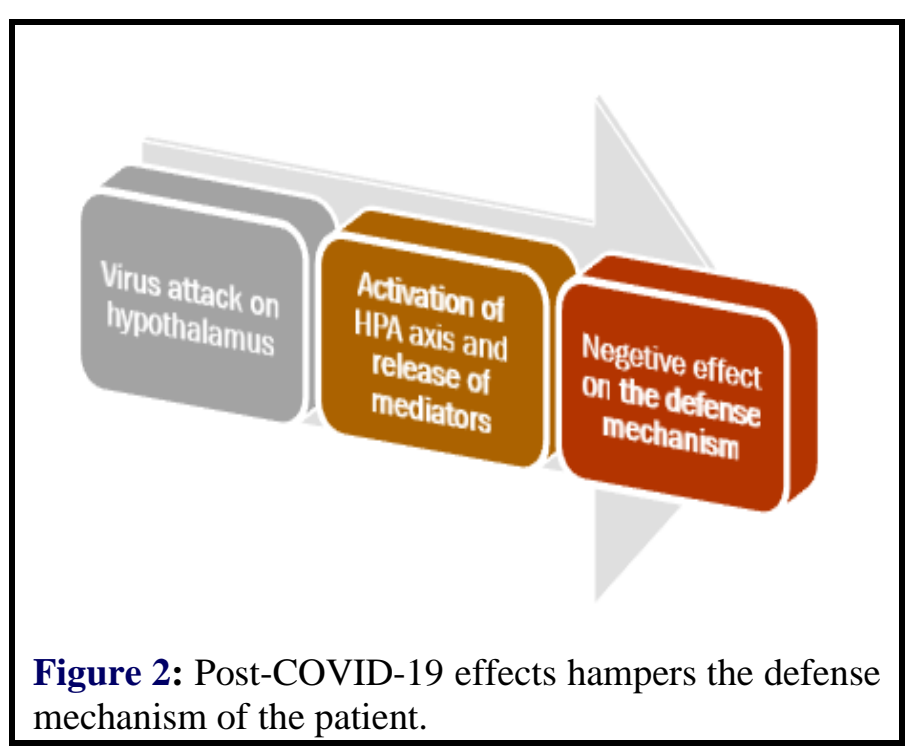

\section{Impact on kidney}

Severe COVID-19 patients have been observed with the signs of kidney damage. Report suggests that $30 \%$ of the patients, which were hospitalized with COVID-19 in China and New York had develop kidney injury. Kidney problem in patients include high percentage of protein in urine. According to the survey, in 147 patients, $60 \%$ were diagnose with proteinuria and $48 \%$ patients were observed with haematuria [25]. It was observed that patients with AKI had higher mortality rate, compare to those who are without AKI $[25,26]$.

According to the studies, the pre-existing kidney disease can become a risk factor especially in older patients [25].
After the recovery from COVID with kidney complication, there are long term effects on urinary system.

\section{Conclusion}

Many people all over the world were infected with COVID-19 and developed post-COVID effects. Though the recovery rate has increased, but people are facing with post-COVID effects. These impact more or less results from pre-existing cardiovascular, respiratory and urinary diseases. The long term effects are seen with the patients who recovered from serious infection. It has a dangerous effect on nervous system. The virus "severe acute respiratory syndrome coronavirus 2" (SARS-Co-V-2) has bad effect on all organ systems of the body.

\section{Conflict of Interest}

None

\section{Funding}

None

\section{References}

1. del Rio C, Collins LF, Malani P. Long-term Health Consequences of Covid-19. JAMA 2020; 324: 17.

2. Jahangir MA, Muheem A, Rizvi MF, et al. Coronavirus (COVID-19): History, Current Knowledge and Pipeline Medications. Int J Pharm Pharmacol 2020; 4: 140.

3. Ghalib RM. Letter to Editor: Vitamin D Fighting Against Novel Coronavirus (SARS-CoV-2). Int J Pharm Pharmacol 2020; 4: 147.

4. Habib A, Ashraf Z, Principe UE, et al. Letter to Editor: Zoonotic Perspective of 2019 Novel Coronavirus Disease (COVID-19). Int J Pharm Pharmacol 2021; 5: 149.

5. Mudenda S. Letter to Editor: Coronavirus Disease (COVID-19): A Global Health Problem. Int J Pharm Pharmacol 2020; 4: 141.

6. Greenhalgh T, Knight M, A'Court C, et al. Management of post-acute Covid-19 in primary care. BMJ 2020; 370: m3026.

7. Tenforde MW, Kim SS, Lindsell CJ, et al. Network Investigators CDC COVID-19 Response Team, IVY Network Investigators. Symptom duration and risk factors for delayed return to usual health among outpatients with COVID-19 in a multistate health care system network - United States. MMWR Morb Mortal Wkly Rep 2020; 69: 993-998. 
8. Dasgupta A, Kalhan A, Kalra S. Long term complication and rehabilitation of Covid-19 patients. J Pak Med Assoc 2020; 70: s131-135.

9. Assaf G, Davis H, Mc Corkell L, et al. An analysis of the prolonged COVID-19 Symptoms Survey by Patient-Led Research Team. Patient Led Research, 2020.

10. Buxton S. How Does COVID-19 Infection Affect Long Term Lung Function? 2020.

11. Gemeli Against COVID-19 Post-Acute care Study Group. Post-COVID-19 global health strategies: the need for an interdisciplinary approach. Aging Clin Exp Res 2020; 32: 1613-1620.

12. Udwadia ZF, Koul PA, Richeldi L. Post-COVID lung fibrosis: The tsunami that will follow the earthquake. Lung India 2020

13. Yu M, Liu Y, Xu D, et al. Prediction of the development of pulmonary fibrosis using serial thin- section CT and clinical features in patients discharged after treatment for COVID-19 pneumonia. Korean J Radiol 2020; 21:746-755.

14. Soumya RS, Unni TG, Raghu KG. Impact of COVID-19 on the Cardiovascular System: A Review of Available reports. Cardiovasc Drugs Ther 2020: 1-15.

15. Casella M, Rajnik M, Cuomo A, et al. Features, evaluation and treatment coronavirus (COVID-19). Stat Pearls [internet] Treasure Island: Stat Pearls; 2020.

16. Li W, Moore MJ, Vasilieva N, et al. Angiotensin converting enzyme 2 is a functional receptor for the SARS coronavirus. Nature. 2003; 426: 450-4

17. Forte G, Favieri F, Tambelli R, et al. COVID-19 pandemic in the Italian population: validation of a post-traumatic Stress disorder questionnaire and prevalence of PTSD symptomatology. Int J Environ Res Public Health 2020; 17:4151.

18. Schafer SK, Sopp MR, Schanz CG, et al. Impact of COVID-19 on Public Mental Health and the Buffering Effect of a Sense of Coherence Psychother Psychosom 2020; 89: 386-392.

19. Rose N, Manning N, Bentall R, et al. The social underpinnings of mental distress in the time of COVID-19 - time for urgent action [preprint]. Wellcome Open Res 2020.

20. Wan L, He W, Yu X, et al. Coronavirus disease 2019 in elderly patients: Characteristics and prognostic factors based on 4-weeks follow-up. J Infect 2020; 80:639-45.

21. Kemp HI, Corner E, Colvin LA. Chronic pain after COVID-19: implication for rehabilitation. $\mathrm{Br} \mathrm{J}$ Anaesth 2020; s0007-0912(20)30403-7.

22. Varatharaj A, Thomas N, Ellul MA, et al. Coro Nerve Stuy Group. Neurological and neuropsychiatric complications of COVID-19 in 153 patients: a UK- wide surveillance study. Lancet Psychiatry 2020; s2215-0366(20)30287-x.

23. Ladecola C, Anrather J, Kamel H. Effects of COVID-19 on the Nervous System. Cell 2020; 183.

24. Dantzer R. Neuroimmune Interactions: From the Brain to the Immune System and Vice Versa. Physiol Rev 2018; 98: 477-504.

25. Benedetti C, Waldman M, Zaza G, et al. COVID19 and the Kidneys: An Update. Frontiers in Med 2020; 7: 423.

26. Hirsh JS, Ng JH, Ross DW, et al. Acute kidney injury in patients hospitalized with COVID-19. Kidney Int 2020; 98: 209-218.

This manuscript was peer-reviewed

Mode of Review: Single-blinded

Academic Editor: Dr. MA Jahangir

Copyright: (92021 Lonkar and Gosavi. This article is distributed under the terms of the Creative Commons Attribution 4.0 International License (http://creativecommons.org/licenses/by/4.0/), which permits unrestricted use, distribution, and reproduction in any medium, provided you give appropriate credit to the original author(s) and the source, provide a link to the Creative Commons license, and indicate if changes were made.

(cc) Br 